\title{
Improvement of Job Satisfaction through Transformational Leadership, Personality, and Achievement Motivation by Using Scientific Identification Theory of Operation Research in Education Management (SITOREM)
}

\author{
Moudy E. U. Djami*, Soewarto Hardhienata, Martinus Tukiran \\ Post Graduate Program, Pakuan University Bogor, Indonesia
}

*Corresponding Author: Moudy E. U. Djami, Post Graduate Program, Pakuan University Bogor, Indonesia

\begin{abstract}
Job satisfaction is an essential element in the achievement of educational goals to produce excellent quality and globally competitive graduates. The purpose of this study was to identify the relationship of transformational leadership, personality and achievement motivation with job satisfaction of lecturers.

This research uses explanatory sequential design. The population of this study was 145 midwifery lecturers, with a sample of 108 lecturers. Quantitative data were collected by questionnaires, and statistical analysis was used regression correlation. The Scientific Identification Theory of Operation Research in Education Management (SITOREM) analysis method is used to make recommendations and determine the priority sequence of improvements that need to be made. Qualitative data were collected by observation, in-depth interview, documents analysis and focus group discussion. The results of 108 lecturers of the Midwifery Academy in Banten, West Java, Indonesia showed that all variables were positively related to lecturer job satisfaction in a row according to the strength of the strongest correlation were achievement motivation $(r=$ 0.819, $\rho<0,01)$, Transformational Leadership $(r=0.797, \rho<0.01)$, and Personality $(r=0.650, \rho<0.01)$ Consistent with the quantitative results, the qualitative data analysis also shows that job satisfaction can be improved through increased lecturer achievement motivation, good lecturer personality and the application of transformational leadership by the leader.The results of the SITOREM analysis showed that the components of job satisfaction, achievement motivation, transformational leadership and personality of lecturers which needed priority to improve were: 1)understanding of self-ability, 2)responsibility of solving problems, 3) goals, and 4)independence.
\end{abstract}

Keywords: achievement motivation, job satisfaction, personality, transformational leadership, SITOREM analysis.

\section{INTRODUCTION}

The role of education is very critical in improving welfare to achieve a nation's prosperity. Countries that prioritize education in development program strategies have proven to be superior to other countries in various fields. This can be achieved if education is managed correctly. As a comparison of the Human Development Index (HDI) in 2018, Indonesia is lower than neighboring countries where Indonesia ranks 116th, Thailand 83rd, Malaysia 57th, Brunei Darussalam 39th, and Singapore 9th.

Quality education is not only essential to produce educated individuals and communities, but it is also vital in the preparation of the younger generation to enter the global competition, a competition between nations that is so tight and related to all dimensions of human life. Global competitiveness in 2017-2018 indicates that Indonesia is still below when compared to other ASEAN countries, which is ranked 36th, Malaysia 23rd, and Singapore 3rd. The quality of good education also determines the quality of a nation that can increase the dignity of the nation.

To be able to win the competition, there needs to be good management of education. The management of good education emphasizes the efforts of education management to improve the quality of education. The quality of education is influenced by several factors. These factors include the curriculum, learning process, Human Resources (HR), infrastructure and facilities, finance, research, and community service as well as governance. 
Improvement of Job Satisfaction through Transformational Leadership, Personality, and Achievement Motivation by Using Scientific Identification Theory of Operation Research in Education Management (SITOREM)

The above factors require proper management of educational organizations so that the goals of education can be achieved, namely to produce quality graduates. The things that need to be considered so that this goal can be achieved is managing the determinants of the quality of education appropriately, both at the input, process and output stages. Some efforts that need to be done so that the educational goals can be achieved include lecturers' performance or good human resources, increasing HR work motivation, as well as competence, effectiveness and job satisfaction for both lecturers and other education personnel.

Job satisfaction today is an important target in human resource-based management because it will directly or indirectly affect work productivity. At the tertiary level, lecturer job satisfaction is crucial in determining the development of the institution concerned. If lecturer satisfaction is low, it is predicted to cause symptoms such as low work performance, some complaints, low quality of teaching, lazy to work, indiscipline, frequent absence, and other symptoms. This certainly has an impact on the quality of the learning process that is low and ultimately produces graduates of poor quality.

Based on the results of preliminary research, it is known that there are still gaps in lecturers' job satisfaction from the aspects of wages, supervision, co-workers, awards, work conditions, and promotions. Therefore it is necessary to research job satisfaction and related factors. This study will focus on the relationship of job satisfaction with transformational leadership factors, personality and achievement motivation in lecturers so that recommendations to increase job satisfaction can be obtained through these factors. The findings of this study are expected to be able to add knowledge, especially for higher education leaders in the midwifery academy in managing respective institutions, especially in terms of strategies for increasing job satisfaction that have an impact on productivity and improving the quality of graduates.

In general, this study aims to solve the problem of lecturer job satisfaction and variables consideredto have a relationship are transformational leadership, personality and achievement motivation.

\section{LITERATURE REVIEW}

Job satisfaction according to Ivancevich et al. (2008) is the feelings, beliefs, and attitudes that employees have towards their work. The things that make the level of satisfaction vary are the extent to which they view the following: (a) work as a primary interest in life, (b). Levelof participation in work, (c). A job as the core of self-esteem, and (d). Work as a thing consistent withown concept. A person who is not involved in work or organization where he works, cannot be expected to feel the same satisfaction compared to those who are more involved.

Schemerhon (2011) formulates job satisfaction as a degree where a person feels positive or negative related to their work. Job satisfaction factors include: (a) Job conditions themselves, namely responsibility, interest, and work growth, (b) Quality of supervision, namely technical guidance, and social support obtained, (c) Relationships with colleagues, namely social harmony and mutual respect; (d). Promotion opportunities, namely changes to future progress, and (e). Wages that are adequate and fair rewards.

In line with this view, Colquit et al. (2011), suggest the notion of job satisfaction is a pleasant emotional state that results from the assessment of one's work or work experience. There are 5 factors that are most desirable and enjoyed by employees in work, namely: (a). High and definite salary, (b). Promotion opportunities based on performance and ability, (c). Supervision of supervisor, namely the good working relationship with boss and award, (d). Work colleagues, namely good relations between responsible colleagues, and (e). The work itself is the freedom to realize capabilities, creations, achievements and so on.

Based on various descriptions of job satisfaction above, it can be synthesized the notion of job satisfaction is the feeling of someone positive towards his job as a result of their perception of the work itself. Job satisfaction can be measured through indicators: (a) Wages include salary amount, salary payment time, salary payment method, (b) Working conditions namely whether the job is seen as a challenge or just a boring routine, (c). Promotion opportunity, covering the period of promotion, competition against promotions, limited positions available, and evaluations from superiors, (d) 
Improvement of Job Satisfaction through Transformational Leadership, Personality, and Achievement Motivation by Using Scientific Identification Theory of Operation Research in Education Management (SITOREM)

Supervision, namely the ability and professionalism of supervisors in technical and psychological and social matters, (e). Work partners, namely compatibility, mutual build and be able to work together and have a bonding attachment, and (f). Awards namely an objective assessment of the award, the time of awarding and the type of award received.

Transformational leadership according to Yukl (2013) is leadership that fosters followers' trust, admiration, loyalty,and respect for leaders and is motivated to do more than initial expectations. The dimensions of transformational leadership are (a) Idealized influence, namely, behavior that arouses emotions and strong identification of followers towards their leaders, (b). Individual consideration, namely the act of providing support, encouragement and enthusiasm and guidance to followers, (c). Inspirational motivation, including communication, introduces compelling visions by using symbols and focuses the boss on the efforts made by subordinates, (d). Interactive stimulation, which is behavior that increases followers' awareness of problems and influences followers to look at problems from a new perspective.

According to Daft (2010), transformational leadership is leadership that can bring innovation and change in organizations. Change is done with their special abilities, recognizing what their followers need and concern, helping them see problems from different perspectives, and encouraging them to question the status quo. Furthermore, Daft explains the dimensions of transformational leadership, namely: (a). Charisma, (b). Individual attention and (c). Intellectual stimulation. Transformational leaders not only make their trust in their leaders personal but also make their followers believe in their abilities, to imagine and create a better future for the organization. Transformational leaders create change not only in organizations but also in their followers.

Transformational leadership according to Colquitet al. (2011) is leadership that involves the inspiration of all its members to be committed in order to lead a shared vision, which at the same time becomes a role model to help followers develop their potential and see problems from a new perspective. Its dimensions are: (a). Ideal influence (charisma), namely leader behavior that raises admiration, trust, and respect from followers, (b). Inspirational motivation is a leader behavior that fosters enthusiasm and commitment to a shared vision in the future, (c) Intellectual stimulation, namely the behavior of leaders who challenge followers to be innovative and creative by questioning assumptions and framing old situations in new ways, (d). Individualized considerations, namely behavioral leaders who help followers reach their potential through coaching, development and mentoring. The higher the influence of the leader on the mindset or idealism of his followers, the easier it is for leaders to stimulate the intellectuals and motivations of their followers.

Based on the various descriptions of transformational leadership above, it can be synthesized the notion of transformational leadership is the behavior of a leader who can inspire and motivate followers, provide intellectual stimulation and attention individually, by first becoming an example then encouraging them to utilize their respective strengths and weaknesses to achieving organizational goals exceed what is expected. Transformational leadership can be measured through indicators: (a). Idealized influenced, namely leaders can instill value, respect and pride and trust in each subordinate; (b). Inspirational motivation; (c) intellectual stimulation that is a leader who can encourage followers to view problems with different perspectives and promote awareness and rationalization in looking at and solving problems; and (d). Individual consideration / giving individual attention.

Moorhead and Griffin (2013) concluded that personality is a series of psychological attributes that are relatively stable, which distinguishes someone from others. There is a long debate between psychologists regarding the notion of personality. Personality is often expressed as "nature versus nurture," is the level at which personality attributes are derived from parents (original arguments) or formed by the environment (upbringing arguments). Both natural and environmental factors together shape a person's personality. Personality according to Ivancevichet al. (2008) is "a term of use for describing a great many feelings and behaviors." Personality is a term used to describe a person's feelings and behavior.

Meanwhile,Colquitet al. (2011) concluded that personality refers to structures and tendencies in society, which explain their characteristic patterns in thinking, emotions, and behavior. The better the tendency in the community, the better the person's personality. 
Improvement of Job Satisfaction through Transformational Leadership, Personality, and Achievement Motivation by Using Scientific Identification Theory of Operation Research in Education Management (SITOREM)

Moorhead and Griffin (2013) explain The Big Five Personality Dimensions are fundamental characteristics that are relevant to the organization, and most scientists agreed to the Big Five as a reliable measurement (Rajiani, 2010). The Big Five are measured by indicators: (a). Conscientiousness or prudence, namely being friendly, socializing, and assertive, (b). Agreeableness or friendliness that is good at getting along, kind, cooperative, sympathetic, helpful, warm, pleasant, polite, empathy is forgiving, understanding, and caring and can trust others, (c). Emotional Stability is a way to deal with stress by staying calm, not anxious, the person who is strong, focused and confident, (d). Openness to Experience which is having interest broad and imaginative, always curious, creative, complex, complicated, refined, polite, artistic, sensitive, and interested and willing to consider new ideas, and (e) Extroversion which is being assertive and comfortable in dealing with others, passionate, assertive, brave, friendly and dominant.

Wood et al. (2001) explained that the theory of achievement motivation was developed by David Clarence McClelland and his colleagues in 1940. The theory of achievement motivation is defined as the desire to do the best or more efficiently, solve problems or master difficult tasks.

McClelland in Ivancevichet al. (2008) suggests that when a person's needs are intense, the effect is to motivate people to use behaviors that lead to satisfaction. For example, needing high achievement in a person will make him or her compelled to set challenging goals, work hard to achieve these goals and use their abilities and skills to achieve success. The factors that reflect people with high achievement motivation include: (a) like taking responsibility for solving problems; (b). Choose moderate successes and tend to take calculated risks, and (c). Want feedback or assessment of its performance.

Based on the various descriptions above, it can be synthesized the notion of achievement motivation is a strong desire in someone who encourages him to be superior to others in completing his work. Achievement motivation can be measured through indicators: (a). A strong desire to succeed which is to have any targets to do must succeed; (b). Determine reasonable goals and objectives which tend to choose reasonable or achievable goals and objectives; (c). Require feedback that is wanting to know the extent to which they have succeeded or the deficiencies that still exist in order to become experienced and improvement in the future; (d). Hard workers are tough because they want to complete their work with their efforts and abilities; (e). Advantages, namely always wanting to be the best or better than others; (f). Understanding of one's ability to know the strengths and weaknesses of oneself; (g) Independent, which is more pleased if they work independently; and (h). Responsible for solving problems, namely feeling challenged to solve problems that are complicated by their abilities.

Based on the above description, the following hypothesis is postulated:

- There is a positive relationship between job satisfaction and transformational leadership.

- There is a positive relationship between job satisfaction and personality.

- There is a positive relationship between satisfaction and achievement motivation.

- There is a positive relationship between transformational leadership, personality, and achievement motivation altogether with job satisfaction.

\section{MeTHOdOLOGY}

The research was conducted inMidwifery Academy inBanten Province, Indonesia. The time of the study was conducted from 2016 to 2018. The study used a mixmethod design with sequential explanatory. The population of this research was 147 full-timelecturers inthe respective academy. The research employed a proportional random sampling and calculation with Taro Yamane formulagenerated a sample size of 108 lecturers.

The technique data analysis used in this study is descriptive and inferential data analysis techniques. Descriptive data analysis techniques describe what it is about variables, symptom or condition are not intended to test hypotheses. The inferential analysis is used to test hypotheses using regression analysis while the analysis requirements test used to check the significance of the regression and equation linearity. Finally, the Scientific Identification Theory of Operation Research in Education Management (SITOREM) is applied to rank thecritical steps for improvement. 
Improvement of Job Satisfaction through Transformational Leadership, Personality, and Achievement Motivation by Using Scientific Identification Theory of Operation Research in Education Management (SITOREM)

\section{RESULTS AND DISCUSSION}

\subsection{The Relationship between Job Satisfaction and Transformational Leadership}

Based on the results of the study with hypothesis testing it is known that the correlation coefficient between job satisfaction and transformational leadership $=0.797$ with the category of having a strong relationship. The $\mathrm{t}$ value is 13.587> $\mathrm{t}$ table $=2.671$ so $\mathrm{H}_{\mathrm{o}}$ is rejected, leading to the conclusion thatthere is a significant positive relationshipbetween jobsatisfaction and transformational leadership.

Table1: Linearity test and coefficient of correlation of Transformational Leadership $\left(X_{1}\right)$ to Job Satisfaction (Y)

\begin{tabular}{|l|l|l|l|l|l|}
\hline Observation & \multicolumn{1}{|c|}{$\mathbf{R}$} & \multicolumn{1}{|c|}{$\mathbf{R}^{2}$} & $\mathbf{F}_{\text {-test }}$ & $\mathbf{F}_{\text {-table }} \alpha$ & \multirow{2}{*}{ Conclusion } \\
\cline { 1 - 4 } $\mathbf{N}$ & $\mathbf{R}_{\mathbf{x} 1}$ & $\mathrm{r}_{\mathrm{x} 1}$ & $\mathbf{F}_{\mathbf{x} 1}$ & 0.05 & \\
\hline 108 & 0.797 & 0.635 & 1.416 & 1.578 & Significant/Linear \\
\hline
\end{tabular}

The contribution of transformational leadership to job satisfaction is reflected in the value of the determination coefficient of 0.635 or $63.5 \%$, while the remaining $37.5 \%$ is determined by other factors. The quantitative data above is reinforced by data from observations of qualitative research which have the conclusion that transformational leadership qualitatively has the same tendency as transformational leadership in quantitative research. Transformational leadership can have positive implications for job satisfaction because when leaders apply leadership patterns that provide transformation in various ways, there will be a transfer of abilities and motivations and inspiration from leaders to subordinates. Thus the employee will use all of his abilities in order to reach the goal even more than expected as stated by Robbins \& Judge (2013). The results of all that individuals will feel proud of themselves, to be able to meet the higher needs of life, namely self-actualization. With the achievement of work performance, it will lead to individual job satisfaction that will be more productive. Based on the description above, transformational leadership is one of the determining factors in increasing the job satisfaction of Banten Province Midwifery Academy lecturers.

\subsection{The Relationship between Job Satisfaction and Personality}

Based on the results of the study with hypothesis testing it is known that the correlation coefficient between job satisfaction and personality $=0.650$ with the category of having a strong relationship. The $\mathrm{t}$ value is 3.809> $\mathrm{t}$ table $=2.671$ so Ho is rejected, leading to the conclusion that there is a significant positive relationshipbetween jobsatisfaction andpersonality.

Table2: Linearity test and coefficient of correlation of personality $\left(X_{2}\right)$ to Job Satisfaction $(Y)$

\begin{tabular}{|c|c|c|c|c|c|}
\hline Observation & $\mathbf{R}$ & $\overline{\mathbf{R}^{2}}$ & $\mathbf{F}_{\text {-test }}$ & $\mathbf{F}_{\text {-table }} \alpha$ & Conclusion \\
\hline $\mathbf{N}$ & $\mathbf{R}_{\mathrm{x} 2}$ & $r_{x 2}^{2}$ & $\mathbf{F}_{\mathrm{x} 2}$ & 0.05 & \\
\hline 108 & 0.650 & 0.423 & 0.940 & 1.572 & Significant/Linear \\
\hline
\end{tabular}

The coefficient of determination is 0.423 ; meaning $42.3 \%$ of job satisfaction is the result of the workings of personality factors, while the remaining $57.3 \%$ is influenced by other factors. The quantitative data above is strengthened by data from qualitative research observations that have a conclusion that personality qualitatively has a similar tendency to personality in quantitative research. Various studies show that good personality will lead to good job satisfaction as the results of a metaanalysis conducted by Judge, Heller and Mount (2002,) inform that of the five dimensions of personality (Neuroticism, Extraversion, Openness to Experience, Agreeableness, and Conscientiousness) which correlates with job satisfaction is extraversion, Agreeableness and Conscientiousness. Conscientiousness has the strongest correlation among the five personality dimensions. Likewise the results of research by Rotham and Coetzer (2002) who conducted a study of pharmaceutical employees with a sample size of 259 respondents informing that the dimensions of Neuroticism and Extraversion were not related to job satisfaction, but other personality dimensions relate to job satisfaction. Based on the description above, personality is one of the determining factors in increasing job satisfaction.

\subsection{Relationship between Job Satisfaction and Achievement Motivation}

Based on the results of the study with hypothesis testing it is known that the correlation coefficient between job satisfaction and achievement motivation $=0.819$ with the category of having a strong 
Improvement of Job Satisfaction through Transformational Leadership, Personality, and Achievement Motivation by Using Scientific Identification Theory of Operation Research in Education Management (SITOREM)

relationship. The $\mathrm{t}$ value is 14.716> $\mathrm{t}$ table $=2.671$ so Ho is rejected, leading to the conclusion that there is a significant positive relationshipbetween jobsatisfaction andachievement motivation.

Table3: Linearity test and coefficient of correlation of achievement motivation $\left(X_{3}\right)$ to Job Satisfaction $(Y)$

\begin{tabular}{|l|l|l|l|l|l|}
\hline Observation & $\mathbf{R}$ & $\mathbf{R}^{\mathbf{2}}$ & $\mathbf{F}_{\text {-test }}$ & $\mathbf{F}_{\text {-table }} \alpha$ & \multirow{2}{*}{ Conclusion } \\
\cline { 1 - 4 } $\mathbf{N}$ & $\mathbf{R}_{\mathbf{x} 3}$ & $\mathbf{r}^{2}{ }_{\mathbf{x} 3}$ & $\mathbf{F}_{\mathbf{x} 3}$ & 0.05 & \\
\cline { 1 - 3 } & 0.819 & 0.671 & 1.446 & 1.576 & Significant/Linear \\
\hline
\end{tabular}

The contribution of achievement motivation to job satisfaction is reflected in the determination coefficient value of 0.671 , which means that the diversity of job satisfaction levels is $67.1 \%$ determined by achievement motivation, while the remaining $32.9 \%$ is influenced by other factors. That achievement motivation qualitatively has the same tendency as a personality in quantitative research. The results of the Mo and Buavaraporn (2013) study show that good achievement motivation will lead to excellent job satisfaction as the results of research prove that there is a significant difference between the mean score of achievement motivation on job satisfaction high and low job satisfaction, and there is a proven correlation between achievement motivation and job satisfaction, both of which conducted a study of 384 respondents working at department stores in Bangkok, and report that achievement motivation correlates positively with job satisfaction. Based on the description above, it can be concluded that motivation for achievement is one of the determinants of job satisfaction for Midwifery Academy lecturers in Banten province.

\subsection{The Relationship between Job Satisfaction, Transformational Leadership, Personality and Achievement Motivation}

The results showed that there was a significant positive relationship between transformational leadership, personality and achievement motivation with job satisfaction. Based on the results of hypothesis testing the correlation coefficient obtained between transformational leadership, personality and achievement motivation with job satisfaction) was 0.799 , with a probability value of $0.000<0.05$, which means there is a positive relationship significant between transformational leadership, personality and achievement motivation with job satisfaction together. Transformational leadership contribution, personality and achievement motivation towards job satisfaction in the organization amounted to 0.799 which can be interpreted that $79.9 \%$ of diversity in job satisfaction can be explained by the workings of transformational leadership, personality and achievement motivation together. The results of the study are by the existing theories; transformational leadership theory, personality theory and motivation theory including the theory of Northouse (2013) which states transformational leadership is a process that changes a person, concerned with emotions, values, ethics, standards and long-term goals. This includes assessing followers' motives, satisfying their needs, and treating them as human beings as a whole. Transformational leadership includes a form of extraordinary influence, which moves followers to achieve more than what is expected. The results of these studies are also based on personality theory by the theory of McShaneet al. (2012) defining personality as a relatively stable pattern of thoughts, emotions, and behavior which is a characteristic of a person in the psychological process behind its characteristics. The better the mindset, emotions and behavior of a person, the better his personality and Gibson et al. (2012), defining achievement motivation occurs when strong desires emerge in a person, so that desire will be the power to behave that leads to satisfaction because achievement is achieved. For example, workers with high achievement motivation usually determine goals that are challenging in their work, and work hard to achieve them by using all the skills and capabilities they have. Based on the description above, transformational leadership, personality and achievement motivation are determinants in improving lecturers' job satisfaction. This is reinforced by the results of quantitative research which obtained information based on quantitative data through a partial correlation test reinforced by qualitative data that of the three independent variables achievement motivation is more dominant, followed by transformational leadership variables in determining Banten Province Midwifery Academy's job satisfaction.

The relationship among variables is then presentedbyscientific identification theory or operation research in education management (SITOREM) as postulated by Hardhienata (2017). 
Improvement of Job Satisfaction through Transformational Leadership, Personality, and Achievement Motivation by Using Scientific Identification Theory of Operation Research in Education Management (SITOREM)

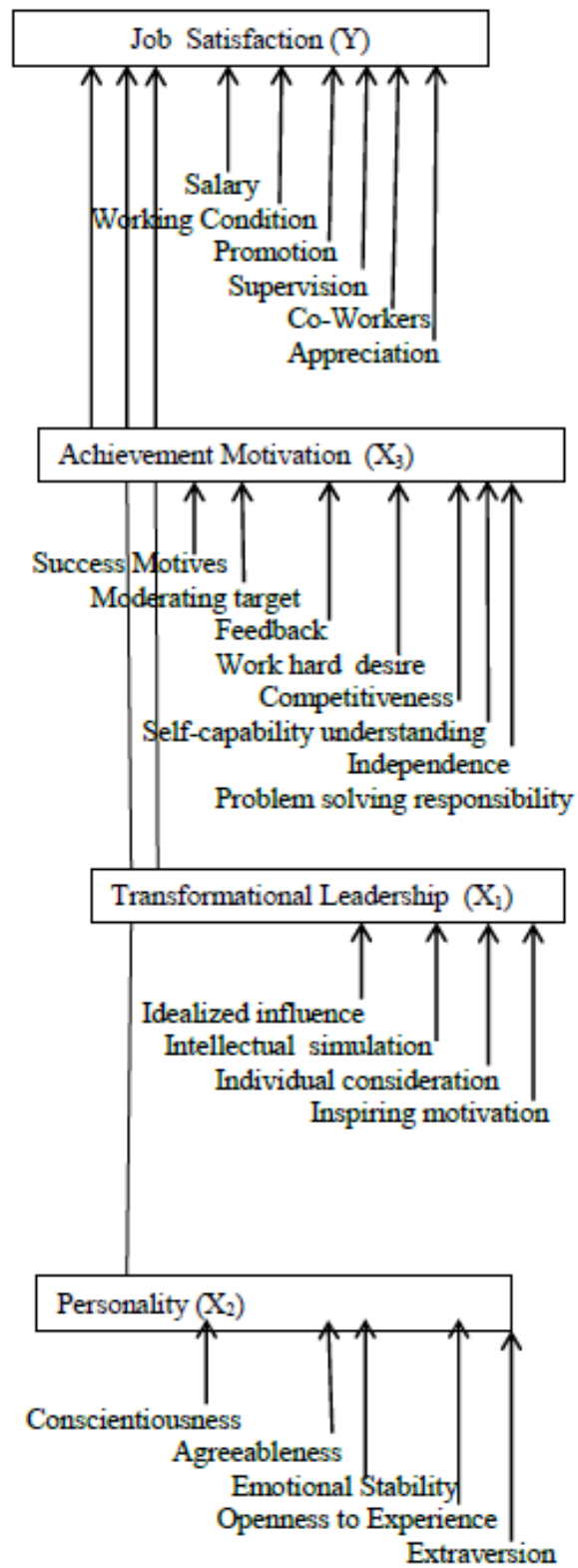

\title{
WEIGHING AND INDICATOR SCORES
}

1.Salary $(30 \%)(3.89)$

2.Supervision (17\%)(4.02)

3.Promotion (15\%)(3.55)

4. Co-Workers $(15 \%)(4.17)$

5.Working Condition (11\%)(3.92)

6. Appreciation $(11 \%)(3.90)$

$\mathrm{R}=0.819$

\section{WEIGHING AND INDICATOR SCORES}

1. Feedback (15\%)(4.91)

2. Self-capability understanding $(15 \%)(3.99)$

3. Problem solving responsibility $(14 \%)(3.92)$

4. Moderating target $(13 \%)(3.54)$

5. Success Motives $(12 \%)(4.20)$

6. Work hard desire $(12 \%)(4.02)$

7. Independence $(9 \%)(3.16)$

8. Competitiveness $(9 \%)(4.04)$

$\mathrm{R}=0.701$

\section{WEIGHING AND INDICATOR SCORES}

\author{
1. Intellectual simulation $(30 \%)(3.95)$ \\ 2. Idealized influence $(27 \%)(3.83)$ \\ 3. Inspiring motivation $(23 \%)(4.22)$ \\ 4. Individual consideration $(20 \%)(4.33)$
}

\section{$\mathrm{R}=0.660$}

\section{WEIGHING AND INDICATOR SCORES}

1. Extraversion $(27 \%)(3.60)$

2. Openness to Experience (24\%)(4.15)

3 Conscientiousness $(20 \%)(4.06)$

4. Emotional Stability $(15 \%)(3.75)$

5. Agreeableness $(14 \%)(4.24)$

Figure1: SITOREM Analysis

Based on the figure, 12 sub-variables needs improving, and also 12 sub-variables may be retained. Those needs improving are:

1. Self-capability understanding

2. Problem-solving responsibility

3. Moderating target

4. Independence

5. Intellectual stimulation

6. Idealized influence

7. Extraversion

8. Emotional Stability 
Improvement of Job Satisfaction through Transformational Leadership, Personality, and Achievement Motivation by Using Scientific Identification Theory of Operation Research in Education Management (SITOREM)

\section{Salary}

10. Promotion

11. Working Condition

12. Appreciation.

While those needs retaining are:

1. Feedback

2. Success Motives

3. Work hard desire

4. Competitiveness

5. Intellectual stimulation

6. Inspiring motivation

7. Individual consideration

8. Openness to Experience

9. Conscientiousness

10. Agreeableness

11. Supervision

12. Co-Workers

\section{CONCLUSION}

Based on the results of data analysis and hypothesis testing in this study, efforts have been found to increase the work satisfaction of lecturers at the Midwifery Academy by identifying the strength of the relationship between the variables of the study and the development of indicators of achievement motivation variables. The relationship between research variables can be formulated as follows: 1) there is a strong and significant positive relationship between transformational leadership with job satisfaction. 2) There is a strong and significant positive relationship between personality and job satisfaction. 3) There is a very strong and significant positive relationship between achievement motivation and job satisfaction. 4) There is a very strong and significant positive relationship between transformational leadership, personality and achievement motivation together with job satisfaction. Based on the findings above, it can be explained that job satisfaction can be improved through the application of transformational leadership by good leadership, the personalityof good lecturers, and high lecturers' motivation both individually and collectively.

\section{REFERENCES}

[1] Colquitt, J.A., J.A Lepine, and M.Wesson. 2011. OrganizationBehaviour,Improving Performance and Commitment in the Workplace. New York: McGraw - Hill International Edition.

[2] Daft, R.L., 2010. New Era of Management, Mason USA: Thomson Higher Education, 2008.

[3] Gibson, J.L., H. James, J. Donnelly, J.M Ivancevich, and R.Konopaske. 2012. Organizations, Behaviour, Structure, Processes. New York: McGraw-Hill International Edition.

[4] Hardhienata, S., 2017.The development of scientific identification theory to conduct operationsresearch in education management, (IOP Conference Series:Materials Science and Engineering) pp.1-6.

[5] Ivancevich, J.M., R. Konopaske, and M.T Matteson. 2008. OrganizationalBehavior and Management, New York: Mcgraw-Hill International Edition.

[6] Judge, T.A., D. Heller, and M.K Mount. 2002. "Five-Factor Model of Personality and Job Satisfaction: A Meta-Analysis" Journal of Applied Psychology. No. 87, pp. 530-541.

[7] Mcshane, S.L. and M.AV.Glinov. 2012. Organizational Behavior, New York: Mcgraw-Hill Irwin.

[8] Moorhead, G., and R.W Griffin.2013. Perilaku Organisasi: Manajemen Sumber Daya Manusia dan Organisasi, (diterjemahkanoleh Diana Angelica), (Jakarta: SalembaEmpat). 
Improvement of Job Satisfaction through Transformational Leadership, Personality, and Achievement Motivation by Using Scientific Identification Theory of Operation Research in Education Management (SITOREM)

[9] Mo, G., and N. Buavaraporn. 2013. "The Studi of Front-Line Employee Motivation In Retailing Business: Empirical Evidence From Department Stores In Bangkok" Utcc-International Journal Of Business and Economic. pp. 119-137.

[10] Northouse, P.G., 2003.Kepemimpinan (diterjemahkanolehAtiCahyani), Jakarta :Indeks.

[11] Rajiani, I.,2010. “Applying Personality Traits to Predict Loyalty and Neglect among Employees of Bank Jatim Located in 10 Big Cities of East Java (Mc Crae's and Hofstede's Theories on the effect of Culture to Personality Revisited)". Jurnal Aplikasi Manajemen, 8, No.3,pp. 617-622.

[12] Robbins, S.P., and T.A Judge. 2013. Organizational Behavior, New Jersey: Pearson Education, Inc.

[13] Rothman, S., and E.P Coetzer. 2002. "The Relationships Between Personality Dimensions And Job Satisfaction" Business Dynamics. No. 11, pp. 29-42.

[14] Schermerhorn.Jr, J.R., J.T. Hunt, R.N Osborn, and M. Uhi-Bien. 2011. Organization Behavior, Pennsylvania: John Willey and Son.

[15] Wood, J., J, Wallace, R. Zeffane, J. Schermerhorn, J. Hunt and R. Osborn.2001.Organizational Behavior: A Global Perspective, Milton, Qld.Australia: John Wiley And Sons Australia, Ltd

[16] Yukl, G., 2010. Leadership in Organization, New Jersey: Pearson.

Citation: Moudy E. U. Djami, Soewarto Hardhienata, Martinus Tukiran. “ Improvement of Job Satisfaction through Transformational Leadership, Personality, and Achievement Motivation by Using Scientific Identification Theory of Operation Research in Education Management (SITOREM)" International Journal of Managerial Studies and Research (IJMSR), vol 7, no. 4, 2019, pp. 62-70. doi:http://dx.doi.org/10.20431/ 2349-0349.0704009.

Copyright: (C) 2019 Authors. This is an open-access article distributed under the terms of the Creative Commons Attribution License, which permits unrestricted use, distribution, and reproduction in any medium, provided the original author and source are credited. 